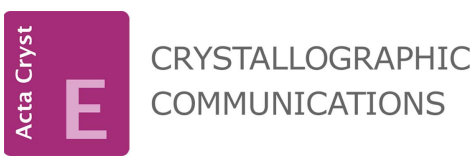

ISSN 2056-9890

Received 6 January 2015

Accepted 24 January 2015

Edited by M. Weil, Vienna University of Technology, Austria

Keywords: crystal structure; tetrawickmanite; mineral structure; polymorphism.

CCDC reference: 1045459 Supporting information: this article has supporting information at journals.iucr.org/e

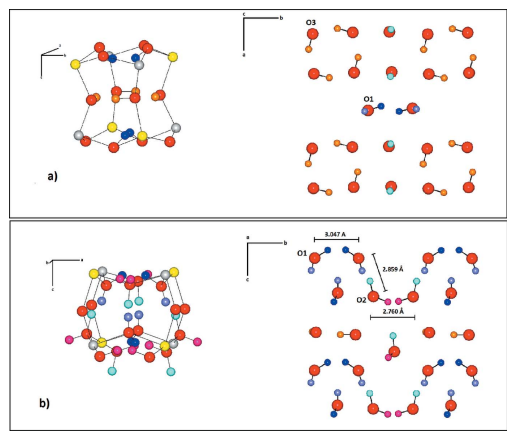

OPEN $\odot$ ACCESS

\section{Crystal structure of tetrawickmanite, $\mathrm{Mn}^{2+} \mathrm{Sn}^{4+}(\mathrm{OH})_{6}$}

\author{
Barbara Lafuente, ${ }^{*}$ Hexiong Yang and Robert T. Downs
}

Department of Geosciences, University of Arizona, 1040 E. 4th Street, Tucson, AZ 85721-0077, USA. *Correspondence e-mail: barbaralafuente@email.arizona.edu

The crystal structure of tetrawickmanite, ideally $\mathrm{Mn}^{2+} \mathrm{Sn}^{4+}(\mathrm{OH})_{6}[$ manganese(II) tin(IV) hexahydroxide], has been determined based on single-crystal X-ray diffraction data collected from a natural sample from Långban, Sweden. Tetrawickmanite belongs to the octahedral-framework group of hydroxideperovskite minerals, described by the general formula $B B^{\prime}(\mathrm{OH})_{6}$ with a perovskite derivative structure. The structure differs from that of an $\mathrm{ABO}_{3}$ perovskite in that the $A$ site is empty while each $\mathrm{O}$ atom is bonded to an $\mathrm{H}$ atom. The perovskite $B$-type cations split into ordered $B$ and $B^{\prime}$ sites, which are occupied by $\mathrm{Mn}^{2+}$ and $\mathrm{Sn}^{4+}$, respectively. Tetrawickmanite exhibits tetragonal symmetry and is topologically similar to its cubic polymorph, wickmanite. The tetrawickmanite structure is characterized by a framework of alternating cornerlinked $\left[\mathrm{Mn}^{2+}(\mathrm{OH})_{6}\right]$ and $\left[\mathrm{Sn}^{4+}(\mathrm{OH})_{6}\right]$ octahedra, both with point-group symmetry $\overline{1}$. Four of the five distinct $\mathrm{H}$ atoms in the structure are statistically disordered. The vacant $A$ site is in a cavity in the centre of a distorted cube formed by eight octahedra at the corners. However, the hydrogen-atom positions and their hydrogen bonds are not equivalent in every cavity, resulting in two distinct environments. One of the cavities contains a ring of four hydrogen bonds, similar to that found in wickmanite, while the other cavity is more distorted and forms crankshaft-type chains of hydrogen bonds, as previously proposed for tetragonal stottite, $\mathrm{Fe}^{2+} \mathrm{Ge}^{4+}(\mathrm{OH})_{6}$.

\section{Mineralogical and crystal-chemical context}

Tetrawickmanite, ideally $\mathrm{Mn}^{2+} \mathrm{Sn}^{4+}(\mathrm{OH})_{6}$, belongs to the octahedral-framework group of hydroxide-perovskites, described by the general formula $B B^{\prime}(\mathrm{OH})_{6}$ with a perovskite derivative structure. The structure of hydroxide-perovskites differs from that of an $A B \mathrm{O}_{3}$ perovskite in that the $A$ site is empty while each $\mathrm{O}$ atom is bonded to a hydrogen atom. The lack of $A$-site cations makes them more compressible than perovskite structures (Kleppe et al., 2012) and elicits an industrial interest for their potential use in hydrogen storage at high pressures (Welch \& Wunder, 2012).

The hydroxide-perovskite species with $B=B^{\prime}$ include dzhalindite $\left[\operatorname{In}(\mathrm{OH})_{3}\right]($ Genkin \& Murav'eva, 1963), bernalite $\left[\mathrm{Fe}^{3+}(\mathrm{OH})_{3}\right]\left(\right.$ Birch et al., 1993) and söhngeite $\left[\mathrm{Ga}(\mathrm{OH})_{3}\right]$ (Strunz, 1965). The species with $B \neq B^{\prime}$ have the two cations fully ordered into $B$ and $B^{\prime}$ sites according to bond-valence constraints on the bridging $\mathrm{O}$ atoms. Valence states can range from $+\mathrm{I}$ to $+\mathrm{III}$ for $B$-site cations and from $+\mathrm{III}$ to $+\mathrm{V}$ for $B^{\prime}-$ site cations.

Tetrawickmanite belongs to the group of hydroxidostannate(IV) perovskites $\left[B \mathrm{Sn}^{4+}(\mathrm{OH})_{6}\right]$ which may exhibit cubic $(P n 3, P n 3 m)$ or tetragonal $\left(P 4_{2} / n, P 4_{2} / n n m\right)$ symmetries. Burtite $(B=\mathrm{Ca})$ (Sonnet, 1981), natanite $\left(B=\mathrm{Fe}^{2+}\right)$ (Marshukova et al., 1981), schoenfliesite $(B=\mathrm{Mg})$ (Faust \& 

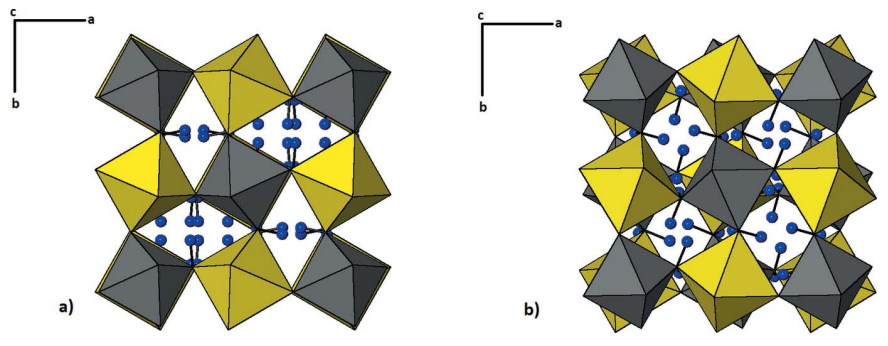

Figure 1

Framework of alternating corner-linked $\left[\mathrm{Mn}^{2+}(\mathrm{OH})_{6}\right]$ and $\left[\mathrm{Sn}^{4+}(\mathrm{OH})_{6}\right]$ octahedra in (a) wickmanite (Basciano et al., 1998) and (b) tetrawickmanite, with change in senses of rotation in alternate layers along the $c$-axis direction. Yellow and grey octahedra represent $\mathrm{Mn}$ and $\mathrm{Sn}$ sites, respectively. Blue spheres represent $\mathrm{H}$ atoms.

Schaller, 1971), vismirnovite $(B=\mathrm{Zn})$ (Marshukova et al., 1981) and wickmanite $\left(B=\mathrm{Mn}^{2+}\right)$ (Moore \& Smith, 1967; Christensen \& Hazell, 1969) display cubic symmetry while tetrawickmanite $\left(B=\mathrm{Mn}^{2+}\right)$, jeanbandyite $\left(B=\mathrm{Fe}^{3+}\right)$ (Kampf, 1982) and mushistonite $\left(B=\mathrm{Cu}^{2+}\right)$ (Marshukova et al., 1984) are tetragonal. The two hydroxide-perovskites stottite $(B=$ $\left.\mathrm{Fe}^{2+}, B^{\prime}=\mathrm{Ge}^{4+}\right)($ Strunz et al. 1958$)$ and mopungite $(B=\mathrm{Na}$, $\left.B^{\prime}=\mathrm{Sb}^{5+}\right)$ (Williams, 1985) are also tetragonal.

Tetrawickmanite was initially described by White \& Nelen (1973) from a pegmatite at the Foote Mineral Company's spodumene mine, Kings Mountain, North Carolina. From the $\mathrm{X}$-ray diffraction pattern and the crystal morphology, they determined that tetrawickmanite exhibits tetragonal symmetry and is topologically similar to its polymorph, the cubic wickmanite. A second occurrence of tetrawickmanite at Långban, Sweden, was reported by Dunn (1978) and

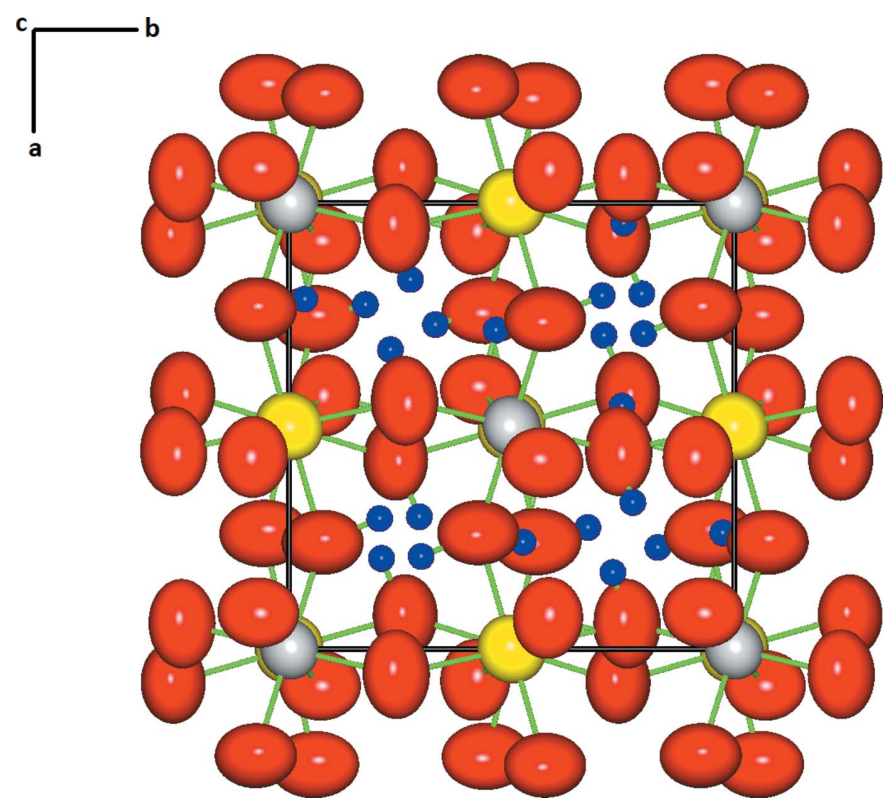

Figure 2

The crystal structure of tetrawickmanite showing atoms with anisotropic displacement ellipsoids at the $99 \%$ probability level. Yellow, grey and red ellipsoids represent $\mathrm{Mn}, \mathrm{Sn}$ and $\mathrm{O}$ atoms, respectively. Blue spheres of arbitrary radius represent $\mathrm{H}$ atoms.
Table 1

Hydrogen-bond geometry $\left(\AA{ }^{\circ}{ }^{\circ}\right)$.

\begin{tabular}{lllll}
\hline$D-\mathrm{H} \cdots A$ & $D-\mathrm{H}$ & $\mathrm{H} \cdots A$ & $D \cdots A$ & $D-\mathrm{H} \cdots A$ \\
\hline $\mathrm{O} 1-\mathrm{H} 1 \cdots \mathrm{O} 1^{\mathrm{i}}$ & $1.10(6)$ & $2.22(7)$ & $3.047(3)$ & $131(4)$ \\
$\mathrm{O} 1-\mathrm{H} 1 \cdots \mathrm{O} 2^{\mathrm{i}}$ & $1.10(6)$ & $2.51(6)$ & $3.0846(19)$ & $111(4)$ \\
$\mathrm{O} 1-\mathrm{H} 2 \cdots \mathrm{O} 2^{\text {ii }}$ & $0.89(7)$ & $1.98(7)$ & $2.859(2)$ & $171(5)$ \\
$\mathrm{O} 2-\mathrm{H} 3 \cdots 2^{\mathrm{iii}}$ & $1.15(7)$ & $1.80(7)$ & $2.760(3)$ & $138(3)$ \\
$\mathrm{O} 2-\mathrm{H} 3 \cdots 1^{\text {iv }}$ & $1.15(7)$ & $2.30(5)$ & $3.140(2)$ & $128(4)$ \\
$\mathrm{O} 2-\mathrm{H} 4 \cdots 1^{\mathrm{v}}$ & $1.11(5)$ & $1.77(5)$ & $2.859(2)$ & $165(5)$ \\
$\mathrm{O}^{\mathrm{O}}-\mathrm{H} 5 \cdots{ }^{\text {vi }}$ & $1.09(3)$ & $1.74(3)$ & $2.752(2)$ & $153(3)$ \\
\hline
\end{tabular}

Symmetry codes: (i) $-x+\frac{3}{2},-y-\frac{1}{2}, z$; (ii) $y+1,-x+\frac{1}{2},-z+\frac{3}{2}$; (iii) $-x+\frac{1}{2},-y-\frac{1}{2}, z$; (iv) $x-\frac{1}{2}, y-\frac{1}{2},-z+1$; (v) $-y+\frac{1}{2}, x-1,-z+\frac{3}{2}$; (vi) $-y+\frac{1}{2}, x,-z+\frac{3}{2}$.

described as tungsten-rich tetrawickmanite with tungsten substituting for tin in the structure.

In the course of identifying minerals for the RRUFF Project (http://rruff.info), we were able to isolate a single crystal of tetrawickmanite from Långban with composition $\left(\mathrm{Mn}^{2+}{ }_{0.94} \mathrm{Mg}_{0.05} \mathrm{Fe}^{2+}{ }_{0.01}\right)_{\Sigma=1}\left(\mathrm{Sn}^{4+}{ }_{0.92} \mathrm{~W}^{6+}{ }_{0.05}\right)_{\Sigma=0.97}(\mathrm{OH})_{6}$.

Thereby, this study presents the first crystal structure determination of tetrawickmanite by means of single-crystal X-ray diffraction.

\section{Structural commentary}

The structure of tetrawickmanite is characterized by a framework of alternating corner-linked $\left[\mathrm{Mn}^{2+}(\mathrm{OH})_{6}\right]$ and $\left[\mathrm{Sn}^{4+}(\mathrm{OH})_{6}\right]$ octahedra, centred at special positions $4 d$ and $4 c$, respectively (site symmetry $\overline{1}$ ) (Fig. $1 b$ ). The $\mathrm{Mn}-\mathrm{O}$ distances are 2.2007 (13), 2.1933 (12) and 2.2009 (14) $\AA$ (average $2.198 \AA$ ) and the $\mathrm{Sn}-\mathrm{O}$ distances are 2.0654 (13), 2.0523 (12) and 2.0446 (13) $\AA$ (average $2.054 \AA$ ), both similar to the interatomic distances determined from neutron powder diffraction data for synthetic wickmanite $(\mathrm{Mn}-\mathrm{O}$ average $2.181 \AA$ and $\mathrm{Sn}-\mathrm{O}$ average $2.055 \AA$; Basciano et al., 1998). The tetrawickmanite structure contains three non-equivalent $\mathrm{O}$ atoms, all protonated as $\mathrm{OH}$ groups and located at general positions. $\mathrm{H} 1, \mathrm{H} 2, \mathrm{H} 3$ and $\mathrm{H} 4$ are statistically disordered within the structure while $\mathrm{H} 5$ is ordered (Fig. 2).

Hydroxide-perovskites have the vacant $A$ site in a cavity in the centre of a distorted cube formed by eight octahedra at the corners. According to the Glazer notation for octahedral-tilt systems in perovskites (Glazer, 1972), wickmanite, the cubic polymorph of tetrawickmanite, is an $a^{+} a^{+} a^{+}$-type perovskite, with three equal rotations (Fig. 1a) while tetrawickmanite is of $a^{+} a^{+} c^{-}$type and it changes the senses of rotation in alternate layers along the $c$-axis direction (Fig. 1b). This difference in octahedral-tilt systems is similar to that observed during compressibility studies of cubic burtite $\left[\mathrm{CaSn}^{4+}(\mathrm{OH})_{6}\right.$; Welch \& Crichton, 2002] and tetragonal stottite $\left[\mathrm{Fe}^{2+} \mathrm{Ge}^{4+}(\mathrm{OH})_{6}\right.$; Ross et al., 2002]. As the authors pointed out, the variance in the octahedral-tilt systems leads to distinct hydrogen-bonding topologies between burtite and stottite, similar to those observed between wickmanite and tetrawickmanite.

Wickmanite has a single type of cavity with the $\mathrm{H}$ atom disordered over two positions, forming a ring of four hydrogen-bonds with two other hydrogen-bonds at the top 


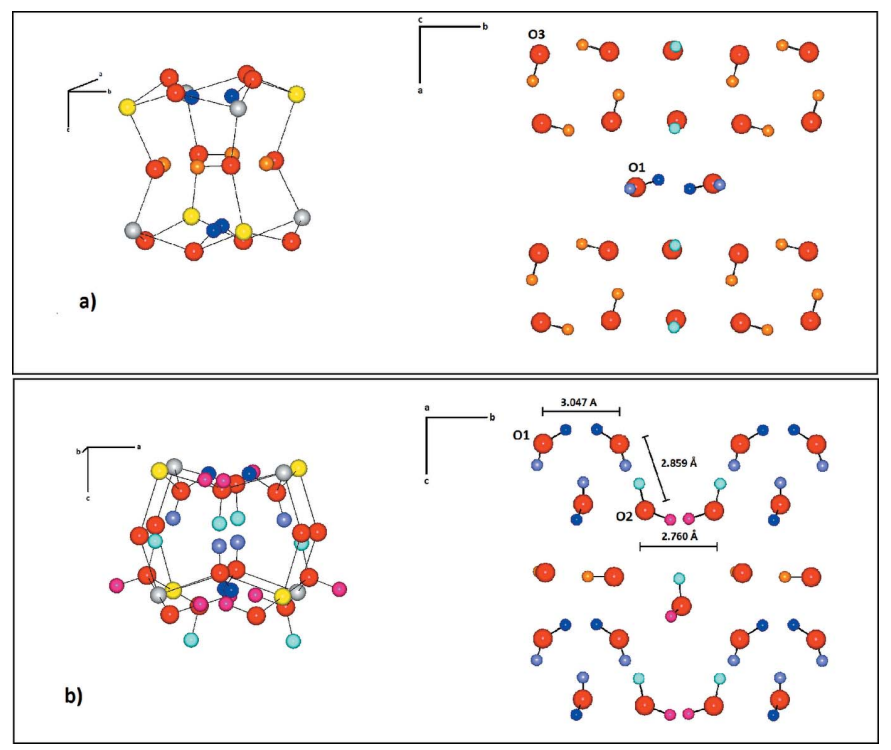

Figure 3

Cavity (left) and hydrogen-bonding linkages (right) in tetrawickmanite. (a) Wickmanite-like cavity with isolated four-membered ring motif O3$\mathrm{H} 5 \cdots \mathrm{O} 3$ and linkages $\mathrm{O} 1-\mathrm{H} 1 \cdots \mathrm{O} 1$ at the top and bottom of the cavity. (b) Sets of $<100>$ crankshaft-type motifs with the isolated four-membered rings lining in the plane perpendicular to the $c$ axis. Yellow, grey and red spheres represent $\mathrm{Mn}, \mathrm{Sn}$ and $\mathrm{O}$ atoms. Blue, purple, pink, aquamarine and orange spheres represent $\mathrm{H} 1, \mathrm{H} 2, \mathrm{H} 3, \mathrm{H} 4$ and $\mathrm{H} 5$ hydrogen atoms, respectively.

and the bottom of the cavity (Basciano et al., 1998). However, in tetrawickmanite, the hydrogen positions and their hydrogen bonds (Table 1) are not equivalent in every cavity, and exhibit two distinct environments. One of the cavities is similar to that of wickmanite, with isolated four-membered hydrogenbonding ring motifs defined by $\mathrm{O} 3-\mathrm{H} 5 \cdots \mathrm{O} 3[2.752(2) \AA]$ and linkages $\mathrm{O} 1-\mathrm{H} 1 \cdots \mathrm{O} 1[3.047(3) \AA]$ at the top and bottom of the cavity (Fig. $3 a$ ). In tetrawickmanite, the fourmembered ring has equal O3...O3 distances [2.752 (2) $\mathrm{A}]$ while in wickmanite, the $\mathrm{O} \cdots \mathrm{O}$ distances alternate between 2.928 and $2.752 \AA$. Presumably, the shorter $\mathrm{O} \cdots \mathrm{O}$ distances within the ring motif in tetrawickmanite is correlated with the ordering of the $\mathrm{H} 5$ atom.

The other cavity in tetrawickmanite is more distorted, with the four-membered rings converted into $<100>$ crankshafttype motifs defined by three hydrogen bonds: $\mathrm{O} 2-\mathrm{H} 3 \cdots \mathrm{O} 2$ $[2.760(3) \AA], \mathrm{O} 1-\mathrm{H} 2 \cdots \mathrm{O} 2 / \mathrm{O} 2-\mathrm{H} 4 \cdots \mathrm{O} 1[2.859$ (2) $\AA]$ and $\mathrm{O} 1-\mathrm{H} 1 \cdots \mathrm{O} 1$ [3.047 (3) $\mathrm{A}]$ and the isolated four-membered rings lying in the plane perpendicular to the $c$ axes. The hydrogen bonds $\mathrm{O} 2-\mathrm{H} 3 \cdots \mathrm{O} 1 \quad[3.140(2) \AA]$ and $\mathrm{O} 1-$ $\mathrm{H} 1$. . O 2 [3.085 (2) $\AA$ ] are located between the crankshafts, at the top and the bottom, respectively (Fig. $3 b$ ). There are no hydrogen bonds parallel to [001].

As stated earlier, the compressibilities of cubic burtite and tetragonal stottite, with unit-cell volumes 535.8 and $426 \AA^{3}$, respectively, have been studied and their hydrogen bonding has been compared (Welch \& Crichton, 2002; Ross et al., 2002). By analogy, a study of the compressibility of the polymorphs wickmanite and tetrawickmanite, with much closer

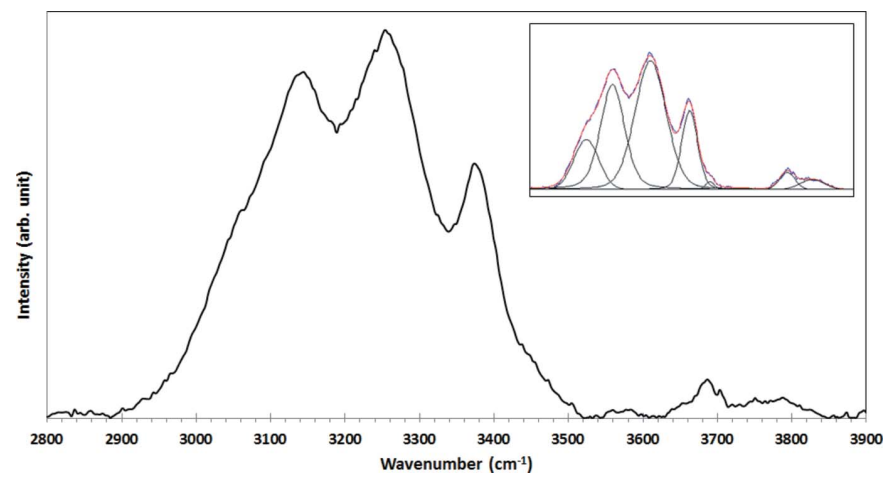

Figure 4

Raman spectrum of tetrawickmanite in the OH-stretching region (2800$3900 \mathrm{~cm}^{-1}$ ). At the top right, the spectral deconvolution obtained with seven fitting peaks using pseudo-Voigt line profiles.

unit-cell volume values (488.26 and $482.17 \AA^{3}$, respectively), might also help in understanding the connection between hydrogen-bonding topologies and compression mechanisms in hydroxide-perovskites.

Kleppe et al. (2012) studied pressure-induced phase transitions in hydroxide-perovskites based on Raman spectroscopy measurements of stottite $\left[\mathrm{Fe}^{2+} \mathrm{Ge}^{4+}(\mathrm{OH})_{6}\right]$ up to $21 \mathrm{GPa}$. In their work, they proposed the monoclinic space group $P 2 / n$ for stottite at ambient conditions derived from the presence of six $\mathrm{OH}$-stretching bands in the Raman spectra in the range 3064$3352 \mathrm{~cm}^{-1}$. We refined the structure of tetrawickmanite in space group $P 2 / n\left(R_{1}=0.0215\right)$ and performed the Hamilton reliability test (Hamilton, 1965). The test indicated that the better structural model for tetrawickmanite is based on the tetragonal space group $\mathrm{P}_{2} / n$ at the $92 \%$ confidence level. Moreover, analysis of the anisotropic displacement parameters showed that the tetragonal model displays ideal rigidbody motion of the strong polyhedral groups (Downs, 2000), thus corroborating a tetragonal structure for tetrawickmanite.

The Raman spectrum of tetrawickmanite in the $\mathrm{OH}$ stretching region $\left(2800-3900 \mathrm{~cm}^{-1}\right)$ is displayed in Fig. 4. The minimum number of peaks needed to fit the spectrum in this region (using pseudo-Voigt line profiles) is seven, which is in agreement with the number of hydrogen bonds derived from the structure (Table 1). According to the correlation of $\mathrm{O}-\mathrm{H}$ stretching frequencies and $\mathrm{O}-\mathrm{H} \cdots \mathrm{O}$ hydrogen-bond lengths in minerals by Libowitzky (1999), the most intense peaks $\left(3062,3145,3253\right.$ and $\left.3374 \mathrm{~cm}^{-1}\right)$ are within the range of calculated wavenumbers for the $\mathrm{H} \cdots \mathrm{O}$ distances between 2.75 and $2.86 \AA$ and they correspond to the strongest hydrogen bonds in the structure.

\section{Experimental}

The tetrawickmanite specimen used in this study was from Långban, Sweden, and is in the collection of the RRUFF project (deposition R100003: http://rruff.info/R100003). Its chemical composition was determined with a CAMECA SX100 electron microprobe at the conditions of $20 \mathrm{kV}, 20 \mathrm{nA}$ and a beam size of $5 \mathrm{~mm}$. 
Table 2

Experimental details.

\begin{tabular}{ll}
\hline Crystal data & $\operatorname{MnSn}(\mathrm{OH})_{6}$ \\
Chemical formula & 275.68 \\
$M_{\mathrm{r}}$ & Tetragonal, $P 4_{2} / n$ \\
Crystal system, space group & 293 \\
Temperature $(\mathrm{K})$ & $7.8655(4), 7.7938(6)$ \\
$a, c(\AA)$ & $482.17(5)$ \\
$V\left(\AA^{3}\right)$ & 4 \\
$Z$ & Mo $K \alpha$ \\
Radiation type & 7.74 \\
$\mu\left(\mathrm{mm}^{-1}\right)$ & $0.05 \times 0.05 \times 0.04$ \\
Crystal size (mm) & \\
& \\
Data collection & Bruker APEXII CCD area \\
Diffractometer & detector \\
& Multi-scan $(S A D A B S ;$ Bruker, \\
Absorption correction & $2004)$ \\
& $0.698,0.747$ \\
$T_{\min }, T_{\text {max }}$ & $4394,1272,681$ \\
No. of measured, independent and & \\
$\quad$ observed $[I>2 \sigma(I)]$ reflections & 0.020 \\
$R_{\text {int }}$ & 0.863 \\
$(\text { sin } \theta / \lambda)_{\text {max }}\left(\AA^{-1}\right)$ & \\
Refinement & \\
$R\left[F^{2}>2 \sigma\left(F^{2}\right)\right], w R\left(F^{2}\right), S$ & $0.021,0.056,1.00$ \\
No. of reflections & 1272 \\
No. of parameters & 56 \\
H-atom treatment & All H-atom parameters refined \\
$\Delta \rho_{\text {max }}, \Delta \rho_{\text {min }}\left(\mathrm{e} \AA^{-3}\right)$ & $0.55,-0.54$ \\
\hline
\end{tabular}

Computer programs: APEX2 and SAINT (Bruker, 2004), SHELXS97 and SHELXL97 (Sheldrick, 2008), XtalDraw (Downs \& Hall-Wallace, 2003) and publCIF (Westrip, 2010).

The analysis of thirteen points yielded an average composition (wt. \%): $\mathrm{MnO} 24.47$ (15), $\mathrm{MgO} 0.71$ (11), $\mathrm{FeO}$ 0.34 (19), $\mathrm{SnO}_{2} 50.57$ (15) and $\mathrm{WO}_{3} 4.49(1.21)$ with $\mathrm{H}_{2} \mathrm{O} 19.76$ added to obtain a total close to $100 \%$. The empirical chemical formula, calculated based on six oxygen atoms, is $\left(\mathrm{Mn}^{2+}{ }_{0.94} \mathrm{Mg}_{0.05} \mathrm{Fe}^{2+}{ }_{0.01}\right)_{\Sigma=1}\left(\mathrm{Sn}^{4+}{ }_{0.92} \mathrm{~W}^{6+}{ }_{0.05}\right)_{\Sigma=0.97}(\mathrm{OH})_{6}$.

The Raman spectrum of tetrawickmanite was collected from a randomly oriented crystal on a Thermo-Almega microRaman system, using a $532 \mathrm{~nm}$ solid-state laser with a thermoelectric cooled CCD detector. The laser was partially polarized with $4 \mathrm{~cm}^{-1}$ resolution and a spot size of $1 \mathrm{~mm}$.

\section{Refinement}

Crystal data, data collection and structure refinement details are summarized in Table 2. Electron microprobe analysis revealed that the tetrawickmanite sample studied here contains small amounts of $\mathrm{W}, \mathrm{Mg}$ and Fe. However, the structure refinements with and without a minor contribution of these elements in the octahedral sites did not produce any significant differences in terms of reliability factors or displacement parameters. Hence, the ideal chemical formula $\mathrm{Mn}^{2+} \mathrm{Sn}^{4+}(\mathrm{OH})_{6}$ was assumed during the refinement, and all non-hydrogen atoms were refined with anisotropic displace- ment parameters. All $\mathrm{H}$ atoms were located from difference Fourier syntheses. The hydrogen atoms H1-H4 were modelled as statistically disordered around the parent $\mathrm{O}$ atom. $\mathrm{H}$ atom positions were refined freely; a fixed isotropic displacement parameter $\left(U_{\text {iso }}=0.03 \AA\right.$ ) was used for all $\mathrm{H}$ atoms.

The maximum residual electron density in the difference Fourier map, $0.55 \mathrm{e} \AA^{-3}$, was located at (0.7590 0.53720 .0856$)$, $1.28 \AA$ from $\mathrm{H} 5$ and the minimum, $-0.54 \mathrm{e} \AA^{-3}$, at $(0.7181$ 0.51020 .2313 ), $0.22 \AA$ from H5.

\section{Acknowledgements}

We gratefully acknowledge the support for this study by the NASA NNX11AP82A, Mars Science Laboratory Investigations. Any opinions, findings, and conclusions or recommendations expressed in this publication are those of the author(s) and do not necessarily reflect the views of the National Aeronautics and Space Administration.

\section{References}

Basciano, L. C., Peterson, R. C. \& Roeder, P. L. (1998). Can. Mineral. 36, 1203-1210.

Birch, W. D., Pring, A., Reller, A. \& Schmalle, H. D. (1993). Am. Mineral. 78, 827-834.

Bruker (2004). APEX2, SAINT and SADABS. Bruker AXS Inc., Madison, Wisconsin, USA.

Christensen, A. N. \& Hazell, R. G. (1969). Acta Chem. Scand. 23, 1219-1224.

Downs, R. T. (2000). Rev. Mineral. Geochem. 41, 61-88.

Downs, R. T. \& Hall-Wallace, M. (2003). Am. Mineral. 88, 247-250.

Dunn, P. J. (1978). Miner. Rec. 9, 41-41.

Faust, G. T. \& Schaller, W. T. (1971). Z. Kristallogr. 134, 116-141.

Genkin, A. D. \& Murav'eva, I. V. (1963). Zap. Vses. Miner. Ob. 92 , 445-457.

Glazer, A. M. (1972). Acta Cryst. B28, 3384-3392.

Hamilton, W. C. (1965). Acta Cryst. 18, 502-510.

Kampf, A. R. (1982). Mineral. Rec. 13, 235-239.

Kleppe, A. K., Welch, M. D., Crichton, W. A. \& Jephcoat, A. P. (2012). Mineral. Mag. 76, 949-962.

Libowitzky, E. (1999). Monatsh. Chem. 130, 1047-1059.

Marshukova, N. K., Palovskii, A. B. \& Sidorenko, G. A. (1984). Zap. Vses. Miner. Ob. 113, 612-617.

Marshukova, N. K., Palovskii, A. B., Sidorenko, G. A. \& Chistyakova, N. I. (1981). Zap. Vses. Miner. Ob. 110, 492-500.

Moore, P. B. \& Smith, J. V. (1967). Ark. Miner. Geol. 4, 395-399.

Ross, N. L., Chaplin, T. D. \& Welch, M. D. (2002). Am. Mineral. 87, 1410-1414.

Sheldrick, G. M. (2008). Acta Cryst. A64, 112-122.

Sonnet, P. M. (1981). Can. Mineral. 19, 397-401.

Strunz, H. (1965). Naturwissenschaften, 52, 493-493.

Strunz, H., Söhnge, G. \& Geier, B. H. (1958). Neues Jb. Miner. Mh. 1958, 85-96.

Welch, M. D. \& Crichton, W. A. (2002). Miner. Mag. 66, 431-440.

Welch, M. D. \& Wunder, B. (2012). Phys. Chem. Miner. 39, 693-697.

Westrip, S. P. (2010). J. Appl. Cryst. 43, 920-925.

White, J. S. Jr \& Nelen, J. A. (1973). Miner. Rec. 4, 24-30.

Williams, S. A. (1985). Miner. Rec. 16, 73-74. 


\section{supporting information}

Acta Cryst. (2015). E71, 234-237 [doi:10.1107/S2056989015001632]

\section{Crystal structure of tetrawickmanite, $\mathrm{Mn}^{2+} \mathrm{Sn}^{4+}(\mathrm{OH})_{6}$}

\section{Barbara Lafuente, Hexiong Yang and Robert T. Downs}

\section{Computing details}

Data collection: APEX2 (Bruker, 2004); cell refinement: SAINT (Bruker, 2004); data reduction: SAINT (Bruker, 2004); program(s) used to solve structure: SHELXS97 (Sheldrick, 2008); program(s) used to refine structure: SHELXL97 (Sheldrick, 2008); molecular graphics: XtalDraw (Downs \& Hall-Wallace, 2003); software used to prepare material for publication: publCIF (Westrip, 2010).

\section{Manganese(II) tin(IV) hexahydroxide]}

Crystal data

$\mathrm{MnSn}(\mathrm{OH})_{6}$

$M_{r}=275.68$

Tetragonal, $P 4_{2} / n$

Hall symbol: -P 4bc

$a=7.8655$ (4) $\AA$

$c=7.7938(6) \AA$

$V=482.17(5) \AA^{3}$

$Z=4$

$F(000)=516$

\section{Data collection}

Bruker APEXII CCD area-detector diffractometer

Radiation source: fine-focus sealed tube Graphite monochromator $\varphi$ and $\omega$ scan

Absorption correction: multi-scan

(SADABS; Bruker, 2004)

$T_{\min }=0.698, T_{\max }=0.747$

Refinement

Refinement on $F^{2}$

Least-squares matrix: full

$R\left[F^{2}>2 \sigma\left(F^{2}\right)\right]=0.021$

$w R\left(F^{2}\right)=0.056$

$S=1.00$

1272 reflections

56 parameters

0 restraints

Primary atom site location: structure-invariant direct methods
$D_{\mathrm{x}}=3.798 \mathrm{Mg} \mathrm{m}^{-3}$

Mo $K \alpha$ radiation, $\lambda=0.71073 \AA$

Cell parameters from 1249 reflections

$\theta=4.5-37.8^{\circ}$

$\mu=7.74 \mathrm{~mm}^{-1}$

$T=293 \mathrm{~K}$

Pseudocubic, yellow-orange

$0.05 \times 0.05 \times 0.04 \mathrm{~mm}$

4394 measured reflections

1272 independent reflections

681 reflections with $I>2 \sigma(I)$

$R_{\text {int }}=0.020$

$\theta_{\text {max }}=37.8^{\circ}, \theta_{\min }=3.7^{\circ}$

$h=-11 \rightarrow 7$

$k=-12 \rightarrow 13$

$l=-13 \rightarrow 5$

Secondary atom site location: difference Fourier map

Hydrogen site location: difference Fourier map

All $\mathrm{H}$-atom parameters refined

$w=1 /\left[\sigma^{2}\left(F_{\mathrm{o}}^{2}\right)+(0.022 P)^{2}\right]$

where $P=\left(F_{\mathrm{o}}^{2}+2 F_{\mathrm{c}}{ }^{2}\right) / 3$

$(\Delta / \sigma)_{\max }<0.001$

$\Delta \rho_{\max }=0.55 \mathrm{e}^{-3}$

$\Delta \rho_{\min }=-0.54$ e $\AA^{-3}$

Extinction correction: SHELXL97 (Sheldrick, 2008), $\mathrm{Fc}^{*}=\mathrm{kFc}\left[1+0.001 \mathrm{xFc}^{2} \lambda^{3} / \sin (2 \theta)\right]^{-1 / 4}$

Extinction coefficient: 0.0044 (3) 


\section{Special details}

Geometry. All e.s.d.'s (except the e.s.d. in the dihedral angle between two 1.s. planes) are estimated using the full covariance matrix. The cell e.s.d.'s are taken into account individually in the estimation of e.s.d.'s in distances, angles and torsion angles; correlations between e.s.d.'s in cell parameters are only used when they are defined by crystal symmetry. An approximate (isotropic) treatment of cell e.s.d.'s is used for estimating e.s.d.'s involving 1.s. planes.

Refinement. Refinement of $F^{2}$ against ALL reflections. The weighted $R$-factor $w R$ and goodness of fit $S$ are based on $F^{2}$, conventional $R$-factors $R$ are based on $F$, with $F$ set to zero for negative $F^{2}$. The threshold expression of $F^{2}>\sigma\left(F^{2}\right)$ is used only for calculating $R$-factors (gt) etc. and is not relevant to the choice of reflections for refinement. $R$-factors based on $F^{2}$ are statistically about twice as large as those based on $F$, and $R$ - factors based on ALL data will be even larger.

Fractional atomic coordinates and isotropic or equivalent isotropic displacement parameters $\left(\hat{A}^{2}\right)$

\begin{tabular}{llllll}
\hline & $x$ & $y$ & $z$ & $U_{\text {iso }} * U_{\text {eq }}$ & Occ. $(<1)$ \\
\hline Sn & 0.5000 & 0.0000 & 0.5000 & $0.00790(6)$ & \\
Mn & 0.5000 & 0.0000 & 0.0000 & $0.01017(8)$ & \\
O1 & $0.74065(17)$ & $-0.05652(19)$ & $0.5894(2)$ & $0.0133(3)$ & \\
O2 & $0.42512(19)$ & $-0.23929(17)$ & $0.56923(18)$ & $0.0138(3)$ & \\
O3 & $0.43079(18)$ & $0.08165(18)$ & $0.74014(15)$ & $0.0113(3)$ & \\
H1 & $0.772(7)$ & $-0.171(8)$ & $0.517(7)$ & $0.030^{*}$ & 0.50 \\
H2 & $0.740(7)$ & $-0.025(7)$ & $0.699(9)$ & $0.030^{*}$ & 0.50 \\
H3 & $0.297(9)$ & $-0.292(7)$ & $0.525(4)$ & $0.030^{*}$ & 0.50 \\
H4 & $0.455(8)$ & $-0.252(7)$ & $0.707(7)$ & $0.030^{*}$ & 0.50 \\
H5 & $0.465(4)$ & $0.215(4)$ & $0.743(2)$ & $0.030^{*}$ & \\
\hline
\end{tabular}

Atomic displacement parameters $\left(\AA^{2}\right)$

\begin{tabular}{lllllll}
\hline & $U^{11}$ & $U^{22}$ & $U^{33}$ & $U^{12}$ & $U^{13}$ & $U^{23}$ \\
\hline Sn & $0.00751(11)$ & $0.00801(11)$ & $0.00817(8)$ & $-0.00042(8)$ & $0.00044(6)$ & $0.00029(6)$ \\
Mn & $0.0102(2)$ & $0.0102(2)$ & $0.01012(17)$ & $0.0004(2)$ & $0.00047(14)$ & $0.00021(15)$ \\
O1 & $0.0098(6)$ & $0.0174(7)$ & $0.0128(6)$ & $-0.0002(5)$ & $-0.0011(6)$ & $0.0014(6)$ \\
O2 & $0.0147(7)$ & $0.0091(7)$ & $0.0176(7)$ & $0.0001(5)$ & $0.0009(6)$ & $0.0012(6)$ \\
O3 & $0.0145(7)$ & $0.0107(8)$ & $0.0087(5)$ & $-0.0002(6)$ & $0.0005(5)$ & $-0.0006(5)$ \\
\hline
\end{tabular}

Geometric parameters $\left(A,{ }^{o}\right)$

\begin{tabular}{|c|c|c|c|}
\hline $\mathrm{Sn}-\mathrm{O} 2^{\mathrm{i}}$ & $2.0446(13)$ & $\mathrm{Mn}-\mathrm{O} 3^{\mathrm{ii}}$ & $2.1933(12)$ \\
\hline $\mathrm{Sn}-\mathrm{O} 2$ & $2.0446(13)$ & $\mathrm{Mn}-\mathrm{O} 3^{\mathrm{i}}$ & $2.1933(12)$ \\
\hline $\mathrm{Sn}-\mathrm{O} 3$ & $2.0523(12)$ & $\mathrm{Mn}-\mathrm{O} 2^{\mathrm{iii}}$ & $2.2007(13)$ \\
\hline $\mathrm{Sn}-\mathrm{O} 3^{\mathrm{i}}$ & $2.0523(12)$ & $\mathrm{Mn}-\mathrm{O} 2^{\mathrm{iv}}$ & $2.2007(13)$ \\
\hline $\mathrm{Sn}-\mathrm{O} 1^{\mathrm{i}}$ & $2.0654(13)$ & $\mathrm{Mn}-\mathrm{O} 1^{\mathrm{v}}$ & $2.2009(14)$ \\
\hline $\mathrm{Sn}-\mathrm{O} 1$ & $2.0654(13)$ & $\mathrm{Mn}-\mathrm{O} 1^{\mathrm{vi}}$ & $2.2009(14)$ \\
\hline $\mathrm{O} 2^{\mathrm{i}}-\mathrm{Sn}-\mathrm{O} 2$ & 180.0 & $\mathrm{O} 3^{\mathrm{ii}}-\mathrm{Mn}-\mathrm{O}^{\mathrm{i}}$ & $180.00(7)$ \\
\hline $\mathrm{O} 2{ }^{\mathrm{i}}-\mathrm{Sn}-\mathrm{O} 3$ & $91.66(5)$ & $\mathrm{O} 3^{\mathrm{ii}}-\mathrm{Mn}-\mathrm{O} 2^{\mathrm{iii}}$ & $94.21(5)$ \\
\hline $\mathrm{O} 2-\mathrm{Sn}-\mathrm{O} 3$ & $88.34(5)$ & $\mathrm{O} 3^{\mathrm{i}}-\mathrm{Mn}-\mathrm{O} 2^{\mathrm{iii}}$ & $85.79(5)$ \\
\hline $\mathrm{O} 2^{\mathrm{i}}-\mathrm{Sn}-\mathrm{O}^{\mathrm{i}}$ & $88.34(5)$ & $\mathrm{O} 3^{\mathrm{ii}}-\mathrm{Mn}-\mathrm{O} 2^{\mathrm{iv}}$ & $85.79(5)$ \\
\hline $\mathrm{O} 2-\mathrm{Sn}-\mathrm{O} 3^{\mathrm{i}}$ & $91.66(5)$ & $\mathrm{O} 3^{\mathrm{i}}-\mathrm{Mn}-\mathrm{O} 2^{\mathrm{iv}}$ & $94.21(5)$ \\
\hline $\mathrm{O} 3-\mathrm{Sn}-\mathrm{O}^{3}$ & $180.00(3)$ & 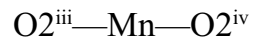 & $180.00(7)$ \\
\hline $\mathrm{O} 2^{\mathrm{i}}-\mathrm{Sn}-\mathrm{O} 1^{\mathrm{i}}$ & $88.67(5)$ & $\mathrm{O} 3^{\mathrm{ii}}-\mathrm{Mn}-\mathrm{O}^{\mathrm{v}}$ & $88.32(5)$ \\
\hline
\end{tabular}




$\begin{array}{llll}\mathrm{O} 2-\mathrm{Sn}-\mathrm{O} 1^{\mathrm{i}} & 91.33(5) & \mathrm{O} 3^{\mathrm{i}}-\mathrm{Mn}-\mathrm{O}^{\mathrm{v}} & 91.68(5) \\ \mathrm{O} 3-\mathrm{Sn}-\mathrm{O} 1^{\mathrm{i}} & 89.84(6) & \mathrm{O} 2^{\mathrm{iii}}-\mathrm{Mn}-\mathrm{O}^{\mathrm{v}} & 88.98(5) \\ \mathrm{O} 3^{\mathrm{i}}-\mathrm{Sn}-\mathrm{O} 1^{\mathrm{i}} & 90.16(6) & \mathrm{O} 2^{\mathrm{iv}}-\mathrm{Mn}-\mathrm{O}^{\mathrm{v}} & 91.02(5) \\ \mathrm{O} 2^{\mathrm{i}}-\mathrm{Sn}-\mathrm{O} 1 & 91.33(5) & \mathrm{O} 3^{\mathrm{ii}}-\mathrm{Mn}-\mathrm{O}^{\mathrm{vi}} & 91.68(5) \\ \mathrm{O} 2-\mathrm{Sn}-\mathrm{O} 1 & 88.67(5) & \mathrm{O} 3^{\mathrm{i}}-\mathrm{Mn}-\mathrm{O} 1^{\mathrm{vi}} & 91.02(5) \\ \mathrm{O} 3-\mathrm{Sn}-\mathrm{O} 1 & 90.16(6) & \mathrm{O} 2^{\mathrm{iii}}-\mathrm{Mn}-\mathrm{O} 1^{\mathrm{vi}} & 88.98(5) \\ \mathrm{O} 3^{\mathrm{i}}-\mathrm{Sn}-\mathrm{O} 1 & 89.84(6) & \mathrm{O} 2^{\mathrm{iv}}-\mathrm{Mn}-\mathrm{O} 1^{\mathrm{vi}} & 180.0 \\ \mathrm{O} 1^{\mathrm{i}}-\mathrm{Sn}-\mathrm{O} 1 & 180.0 & \mathrm{O} 1^{\mathrm{v}}-\mathrm{Mn}-\mathrm{O} 1^{\mathrm{vi}} & \end{array}$

Symmetry codes: (i) $-x+1,-y,-z+1$; (ii) $x, y, z-1$; (iii) $-y, x-1 / 2, z-1 / 2$; (iv) $y+1,-x+1 / 2,-z+1 / 2$; (v) $y+1 / 2,-x+1, z-1 / 2$; (vi) $-y+1 / 2, x-1,-z+1 / 2$.

Hydrogen-bond geometry $\left(\AA,{ }^{\circ}\right)$

\begin{tabular}{lllll}
\hline$D-\mathrm{H} \cdots A$ & $D-\mathrm{H}$ & $\mathrm{H} \cdots A$ & $D \cdots A$ & $D-\mathrm{H} \cdots A$ \\
\hline $\mathrm{O} 1-\mathrm{H} 1 \cdots \mathrm{O} 1^{\text {vii }}$ & $1.10(6)$ & $2.22(7)$ & $3.047(3)$ & $131(4)$ \\
$\mathrm{O} 1-\mathrm{H} 1 \cdots 2^{\text {vii }}$ & $1.10(6)$ & $2.51(6)$ & $3.0846(19)$ & $111(4)$ \\
$\mathrm{O} 1-\mathrm{H} 2 \cdots \mathrm{O} 2^{\text {viii }}$ & $0.89(7)$ & $1.98(7)$ & $2.859(2)$ & $171(5)$ \\
$\mathrm{O} 2-\mathrm{H} 3 \cdots \mathrm{O} 2^{\text {ix }}$ & $1.15(7)$ & $1.80(7)$ & $2.760(3)$ & $138(3)$ \\
$\mathrm{O} 2-\mathrm{H} 3 \cdots 1^{\mathrm{x}}$ & $1.15(7)$ & $2.30(5)$ & $3.140(2)$ & $128(4)$ \\
$\mathrm{O} 2-\mathrm{H} 4 \cdots{ }^{\mathrm{xi}}$ & $1.11(5)$ & $1.77(5)$ & $2.859(2)$ & $165(5)$ \\
$\mathrm{O} 3-\mathrm{H} 5 \cdots{ }^{\mathrm{xi}} 3^{\text {xii }}$ & $1.09(3)$ & $1.74(3)$ & $2.752(2)$ & $153(3)$
\end{tabular}

Symmetry codes: (vii) $-x+3 / 2,-y-1 / 2, z$; (vii) $y+1,-x+1 / 2,-z+3 / 2$; (ix) $-x+1 / 2,-y-1 / 2, z$; (x) $x-1 / 2, y-1 / 2,-z+1$; (xi) $-y+1 / 2, x-1,-z+3 / 2$; (xii) $-y+1 / 2, x,-z+3 / 2$. 